\title{
Quality of the Built Environment from the Infrastructure of Social Interest Housing Developments
}

\author{
Alcindo Neckel ${ }^{1}$, Julian Grub $^{2}$, Caliane Christie Oliveira de Almeida Silva ${ }^{1}$, Maurício Kunz ${ }^{1}$, Lauro André \\ Ribeiro $^{1,3}$, Henrique Aniceto Kujawa ${ }^{1}$, Renata Barbosa Ferrari Curval $^{1}$ and Andrea Quadrado Mussi ${ }^{1}$ \\ 1. School of Architecture and Urbanism of Faculdade Meridional (IMED), Group of Studies and Research on Urban Mobility \\ (NEPMOUR), Passo Fundo/RS CEP 99070-220, Brazil
}

2. Department of Architecture and Urbanism, Federal University of Rio Grande do Sul (UFRGS), Porto Alegre/RS CEP 90040-060, Brazil

3. INESC Coimbra, Coimbra CEP 3030-030, Portugal

\begin{abstract}
The structures in the built environment, particularly concerning morphology are reflected in different allotments, which rely heavily on a technical insight. They are constantly attributed in Brazil by architects, urban planners and geographers, among others, who plan the space and structure them for providing for the population needs. In this context, this research aims to analyze the morphological structure of two social interest housing developments, considering that the lack of efficiency in construction has generated infrastructure problems. Specifically, we analyzed the layout of the two housing developments of social interest, morphology recurrence, layout style adopted, relating their characteristics. Results have shown that the more regular is the topography, the more is the reduction of deployment costs execution of the infrastructure in the housing development. It is believed that this research can provide discussions on the subject and present subsidies to architectural projects.
\end{abstract}

Key words: Morphological analysis, urbanism, urban infrastructure, sustainable strategy.

\section{Introduction}

Globally, the population is increasing constantly in urban areas, causing serious problems in the organizational form of territory. This statement is confirmed by the temporal impossibility for urban planning without reconstruction of the built environment [1-5].

In Brazil, in an attempt to quickly meet the demand for decent housing and adequate living conditions and hygiene in the living spaces, every day, the government proliferate the number of housing developments [6-7]. In this context, the urban socio-spatial structure, particularly the dynamics of space reorganization is characterized as an object of great transformations.

Corresponding author: Alcindo Neckel, Dr., research fields: technology, project and management of the built environment, cemeteries environmental impacts and sustainability.
It is observed, especially in the settlements of social interest, a partial infrastructure in the networks, without taking into account efficiency of the feasibility point of view and the implementation costs, which ultimately result in unpaved streets, carriageway erosion, slope, flooding and drainage problems, especially in cases where the urban layout does not take into account the topography of the land.

In this case, the division of urban land aims to provide the population with infrastructure and adequate services, developing population interaction with the urban environment. Thereby, to provide elements that enhance life quality for the population, there has to be a better selection of areas for the division of land in the urban spaces, whether public or private, it cannot be considered "unhealthy areas, environmentally fragile, unfit for urbanization such as mangroves, banks of rivers and streams, floodplains or steep slopes" [8]. 
These different areas in relation to their different characteristics need to be understood in relation to urban infrastructure, which should be seen as an integrated, dynamic and evolving element. The planning processes of sustainable settlements it should be considered accessibility issues (housing accesses: pedestrians and vehicles), sanitation (supply of drinking water and hygiene, drainage of rainwater, collection and treatment of sewage, disposal of solid and liquid waste) and electricity, and just in a later moment, plan the urban layout $[1,5,8,9]$. This later stage begins with the demarcation of traffic routes (avenues, streets and sidewalks for pedestrians) to organize the different parts of the space and facilitate accessibility.

In this regard, pathways determine different paths and hence housing configuration, which may or may not favor mobility, accesses and road connections, and predefined routes by residents $[1,5,8]$. Hereof, in the case of vehicular roads, in which present an intense traffic, the closed loop is indicated, where a great number of crossroads allows a greater variety of paths allowing alternative routes, higher speeds and easier accesses. On local roads, aiming higher security and privacy, the use of open loop with smaller penetration streets, in which streets guarantee more interaction with residents, since such dead ends have lower traffic flow and stimulate the use of open spaces.

The plot size and shape influence the amount of networks (sewage, power, water and drainage) [1, 9-11]. Likewise, the road system is influenced by population density and the hierarchies of the routes. The plots' layouts are defined into two situations: (1) small plots: adopt closed-loop system in the form of rectangular blocks with contiguous infrastructure networks in front of lots, in which dimensions may not exceed $200 \mathrm{~m}$ long (recommended size for pedestrians accessibility). Layout with good performance regarding financial aspects, in which the block is made up of lots facing two streets, reducing the infrastructure network; (2) large plots: for the partition of large areas of land, they suggest the grid plan, with mixed routes; open and closed [12].

The introduction above contextualizes the object of this research that aims to analyze the morphological structure of the housing development named "Bem-te-vi" in the municipality of Portão/RS (Brazil), and the housing development named "Rio Tigre" in the City of Erechim/RS (Brazil). They are characterized as social interest housings, in which the hypothesis is that the lack of financial efficiency in the implementation stage generated infrastructure problems. Thus, the elements that compose their urban structure were evaluated: pathways and routes; blocks and lots according to their numbers, carriageway size; sidewalk; squares; and urban voids around the settlement as a strategy for implementing low cost sustainable housing developments, especially in relation to infrastructure.

These components connected to the infrastructure need to be considered by designers because housing developments should also be designed for the low-income population, through projects that seek sustainability, reducing installation costs for economically feasible housing [7]. In the decree No.6,766/79 that regulates over the land parceling for urban purposes, it is defined that urban partitions made through lots as "field subdivision into lots for building, with new circulation pathways openings of public streets and facilities or extension, modification or expansion of existing pathways". It also stipulates the proportion of areas intended for circulation systems, urban and community equipment deployment, as well as open spaces for public use with the useful density provided by the legislation.

The study of the urban morphology (shape) presents a qualitative emphasis, considering typological aspects, land partition and use related to cultural and historical elements, as well as in the case of infrastructure, for conformation analysis of urban networks, understood as mutable relationships and constant in time [13]. The study of urban form is 
effective when elements of urban infrastructure are analyzed together (road layout, block, lots and buildings partitions), considering also, among other things, the construction legislation, construction techniques and cultural context in which engineers and architects, particularly, are inserted [14, 15].

\section{Method and Materials}

For the development of this research, two settlements located in different municipalities of Rio Grande do Sul were chosen: the housing developments "Bem-te-vi" in Portão and "Rio Tigre" in the city of Erechim.

The Municipality of Erechim is located in the region of "Alto Uruguai", north of the state of Rio Grande do Sul. It has an estimated population of 102,345 inhabitants and a population density of 223.11 inhabitants $/ \mathrm{km}^{2}$ [16]. In turn, Portão is located in the metropolitan area of Porto Alegre with a population of 30,920 inhabitants. It has a population density of 193.38 inhabitants $/ \mathrm{km}^{2}$ (Fig. 1) [16].

The selection of studied plots correlates to the Brazilian housing deficit problem, understood as the need to build new housing to solve specific problems of housing, and the implementation of low-income housing developments. In Portão, as stated in the Local Plan for Social Housing, it was required 23 million Brazilian reais ( $\mathrm{R} \$$ ) of investments to remedy the deficiencies in housing and infrastructure of the city in 2010 [19]. In the case of Erechim, at the beginning of infrastructure works of the housing development Rio Tigre, there were already 495 families registered at the City Hall for purchasing homes to be built in the lot.

The studies developed in these two housing developments of social interest are characterized by settlements with socioeconomic low-income features; lodging a low-income population, as a result of a social context of exclusion and urban violence. It was also considered: the proponent agent (the government); the architectural design criteria (grid layout, traditional and most frequent method of deployment in the country); urban connections, for comparison purposes as the Bem-te-vi housing was built in a consolidated district, and the Rio Tigre was implemented in non-urban area; and the consolidation period (time of resident occupation). The analysis of the mentioned group of information has provided significant data on the space needs, deficiencies and capabilities.

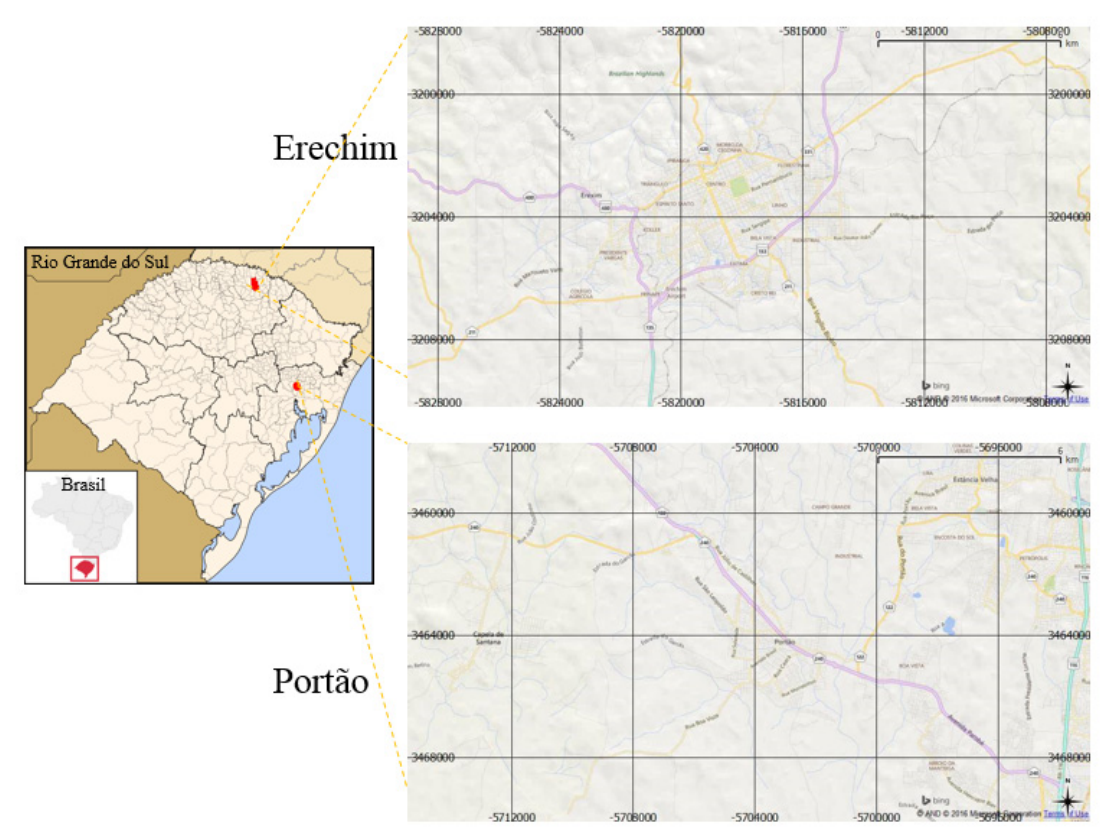

Fig. 1 Location of the municipalities of Erechim and Portão-RS [17, 18]. 
The housing development Bem-te-vi was conceived in 1993 and started being occupied in 1997. It is located in the south of Portão and occupies an area of $100,004.37 \mathrm{~m}^{2}$. It arose from a municipal housing program in 1997 and contains 297 lots. Of these 297 houses, 110 were built in 2000, with state resources to enhance housing (Pró-moradia program) and 20 houses by PSH (Housing Subsidy Program) in 2005 with a municipal supplement of R 2,000.00 per house. There are now 184 regular lots and 115 irregular ones in this housing development.

Rio Tigre was conceived in 2011 and its implementation began in 2012 being promoted by the municipal administration in partnership with a federal program called Minha Casa Minha Vida. Located in the district named Rio Tigre in the southwest area of Erechim, it covers an area of $115,109.61 \mathrm{~m}^{2}$. The project consists of 312 lots of $200 \mathrm{~m}^{2}$ and houses of $53.53 \mathrm{~m}^{2}$.

For developing this research, historical data of the municipalities in question were studied, using primarily the data contained in the Socioeconomic Atlas of Rio Grande do Sul [19]. Subsequently, the master plans of these cities were analyzed, particularly about the territorial divisions, use and occupation of land and infrastructure. More precisely, it was taken into consideration the master plan and its divisions in urban zones with commercial and residential standards for regulation of land use and occupation.

Regarding the survey instruments, the random probability sampling statistical technique was used with the objective of facilitating data gathering and sequential examination of information. Therefore, samples of people living in the housing developments for interviews were collected randomly and systematically. This sampling method allowed to the survey population, in general, the same chances of being selected, increasing the representativeness of the data collected [20].

The surveyed population consists of families that live in the mentioned housings, in which the sample unit is represented by one member of a given household. The sample target population is 297 lots occupied by single-family homes in Bem-te-vi and 312 lots in Rio Tigre. The criteria [21] established require a minimum criterion analysis of $20 \%$ of total lots of a certain housing development to reach sample reliability. In this case, the set values correspond to 60 sample units of Bem-te-vi (Fig. 2) and 63 samples of Rio Tigre (Fig. 3).

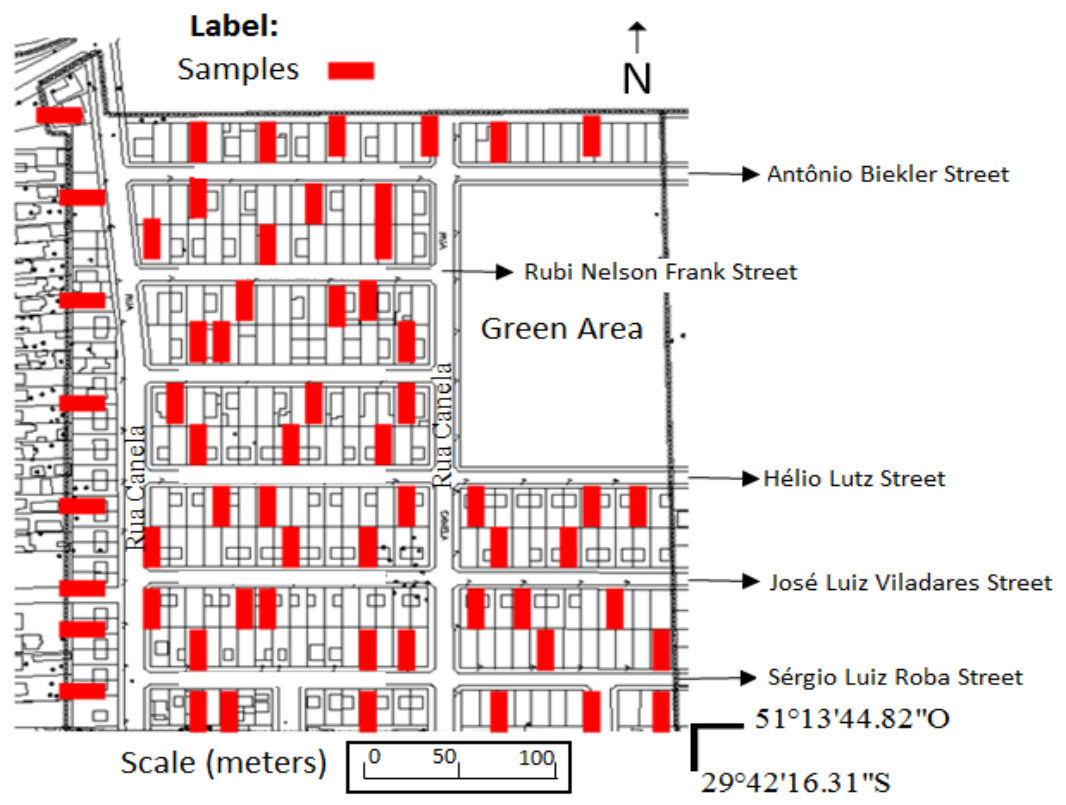

Fig. 2 Sampling map—random lots of Bem-te-vi, Portão/RS [22]. 


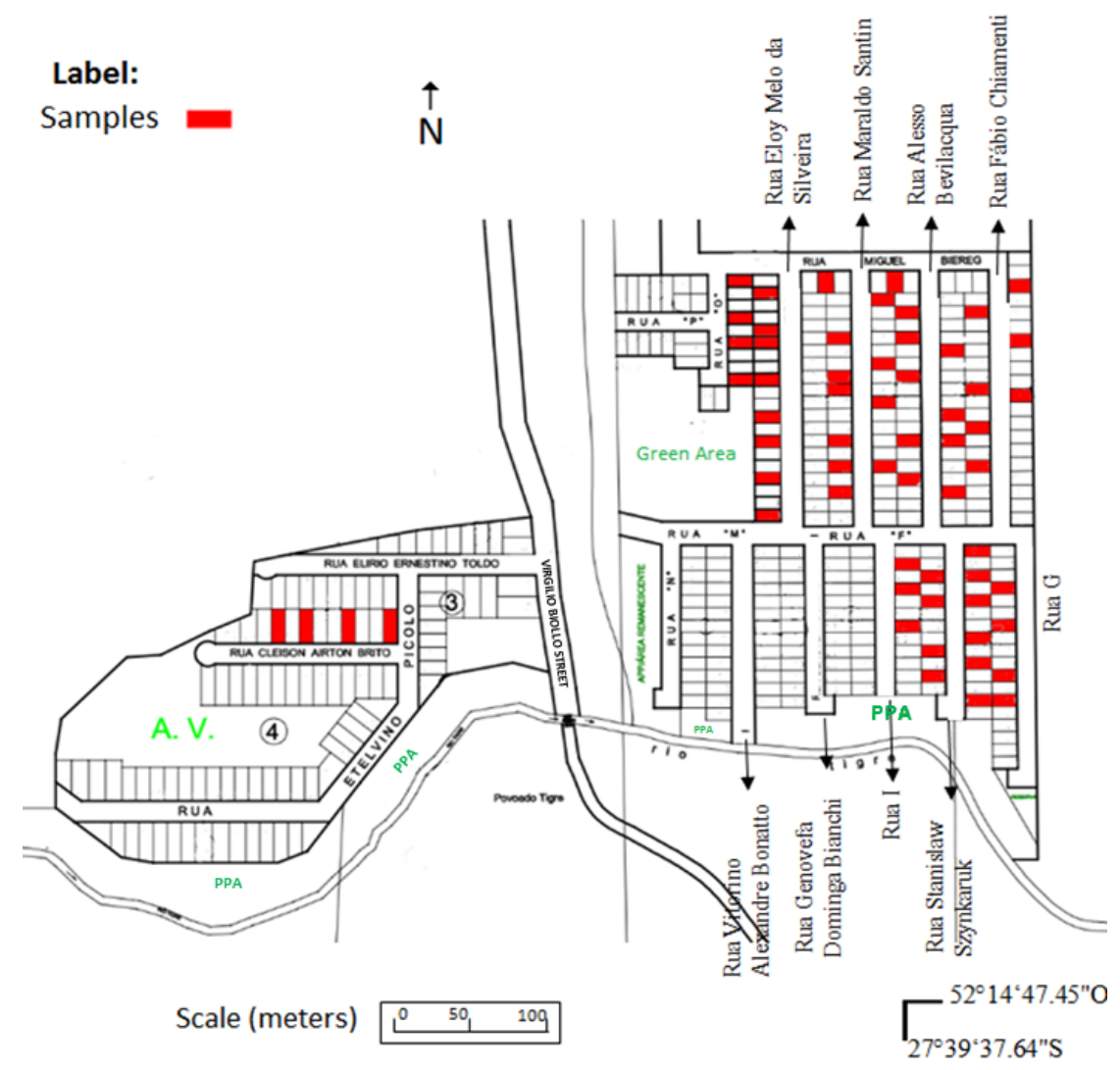

Fig. 3 Sampling map—random lots of Rio Tigre, Erechim/RS [23].

The research instruments provided information for post-occupancy evaluation, in which it became possible to assess the residents' perceptions about their living conditions and infrastructure. The following aspects were considered: residents profile; lot and housing development data; issues relating to the operation of the existing infrastructure in the neighborhood; and the level of satisfaction.

The use and activities developed in both settlements were also identified through a registration form of different physical aspects of ambience and urban infrastructure. This perceptual morphology analysis of Bem-te-vi housing considered the Residential Zone III, defined by the municipal Master Plan (2004) as one of greater housing supply, with more intensive land use and better use of urban infrastructure [22]. It is composed of lots of $160 \mathrm{~m}^{2}$ and facades of $10 \mathrm{~m}$, which may be occupied by buildings with a maximum height of two floors. Thus, it was identified the number of lots for the settlement characteristics (lot size, carriageway size, sidewalk, square, a great void on the border of the settlement).

\section{Results and Discussions}

Emancipated from São Leopoldo in 1863, Portão became part of the São Sebastião do Caí in the early 20 th century. Portão was colonized in the 18th century by the first Portuguese families who received land grants of the crown, in order to make those lands productive, as mentioned in Ref. [19].

In 1788, some housing from Portuguese land grants in the Sinos River Valley were expropriated by the Portuguese "Real Feitoria do Linho e Cânhamo" (The Royal Factory of Flax and Hemp) in 1789. It was built a large gate (Portão, in Portuguese) on the left bank of the past known as Corrêa stream in which named the town and the stream, becoming a reference for travelers for many years. With the bankruptcy of the Real Feitoria, the land that belonged to Portão was the venue for a new settlement for the first German 
immigrants that arrived in Rio Grande do Sul, between 1824 and 1828. At the time, the German families received about 80 hectares of land. The immigration process intensified Portão occupation and resulted in a variety of economic activities whose products were transported to Porto Alegre and São Leopoldo through the Sinos River [22].

The history of the Erechim City dates back to 1908, with the establishment of a town formed by immigrants of Polish, Italian and German origins. With the town's growth and expansion of its economy, it became the District of Passo Fundo, being emancipated in the year 1918. The urban layout of the city of Erechim was inspired by the concepts used in the design of Washington (1791) and Paris (1850) characterized by perpendicular road network cut by diagonal avenues [23].

The master plans of these municipalities established by Municipal Law No. 784, approved on September 23, 1996 in Portão and the Municipal Law No. 2595 of January 4, 1994 in Erechim, state that the plans social functions turn to public and collective rights by: compatibility and use of the property with infrastructure, public facilities and public services; compatibility with preservation, protection and restoration of environmental quality and historical and cultural heritage; use of urban voids and underutilized land; security and health compliance of users; valorization of public investments and private property; planning of the physical space of the city, directing the expansion of urban areas and preserving unsuitable areas for urbanization; ensuring adequate conditions of infrastructure and equipment of collective use for the land receiving urban activities; preservation and enhancement of cultural and natural heritage of the city and environmental protection through land use control; and recognition of the property social function, especially through land regularization and urbanization of areas occupied by low-income population.

In this sense, Portão e Erechim meets what it is established by the City Statute [24], establishing that Municipal Master Plans should contain three elements: management system, structuring the government and civil society; land use planning strategy, defining the social function of property and the city through instruments that regulate urban development; and land regularization and tools that enable projects and priority investments.

As the above-mentioned Master Plan of Portão, the Bem-te-vi housing development is located in the Residential Zone III. The project covers an area of $99,992.32 \mathrm{~m}^{2}$, of which $56.18 \%$ of the total area is occupied by 297 lots, $28 \%$ by road networks, $10.61 \%$ for municipal green area and $5 \%$ for institutional equipment (Tables 1 and 2). It is noteworthy to highlight that the project implementation took advantage of the proximity to São Jorge neighborhood, in order to make use of community facilities located there, school (elementary) and commerce (Fig. 4).

According to the master plan of the City of Erechim, Rio Tigre housing development is located in the Residential Unit 2, where the maximum building height is two floors (Fig. 5). However, unlike Bem-te-vi, this location does not make use of the existing urban network, since its implementation was

Table 1 Housing developments area description.

\begin{tabular}{llllll}
\hline Use & $\begin{array}{l}\text { Bem-te-vi total area } \\
\left(\mathrm{m}^{2}\right)\end{array}$ & $\begin{array}{l}\text { Total percentage } \\
\text { Bem-te-vi }\end{array}$ & $\begin{array}{l}\text { Rio Tigre total area } \\
\left(\mathrm{m}^{2}\right)\end{array}$ & $\begin{array}{l}\text { Total percentage Rio Federal Law } \\
\text { Tigre }\end{array}$ & $\begin{array}{l}\text { - } \\
9,785 / 1999\end{array}$ \\
\hline Road network & $28,007.85$ & $28 \%$ & $33,342.19$ & $29.96 \%$ & $15 \%$ to $20 \%$ \\
Residential lots & $56,175.68$ & $56.18 \%$ & $62,400.00$ & $54.21 \%$ & $55 \%$ to $70 \%$ \\
Facilities & $4,999.62$ & $5 \%$ & $5,921.21$ & $5.14 \%$ & $5 \%$ to $10 \%$ \\
Green area & $10,608.00$ & $10.61 \%$ & $13,446.21$ & $11.68 \%$ & $10 \%$ to $15 \%$ \\
Single lot & 187.00 & - & 200.00 & - & $125 \mathrm{~m}^{2}$ \\
\hline Total area & $99,992.32$ & $100 \%$ & $115,109.61$ & - & - \\
\hline Public area & - & $43.61 \%$ & - & $45.79 \%$ & $35 \%$ \\
\hline
\end{tabular}




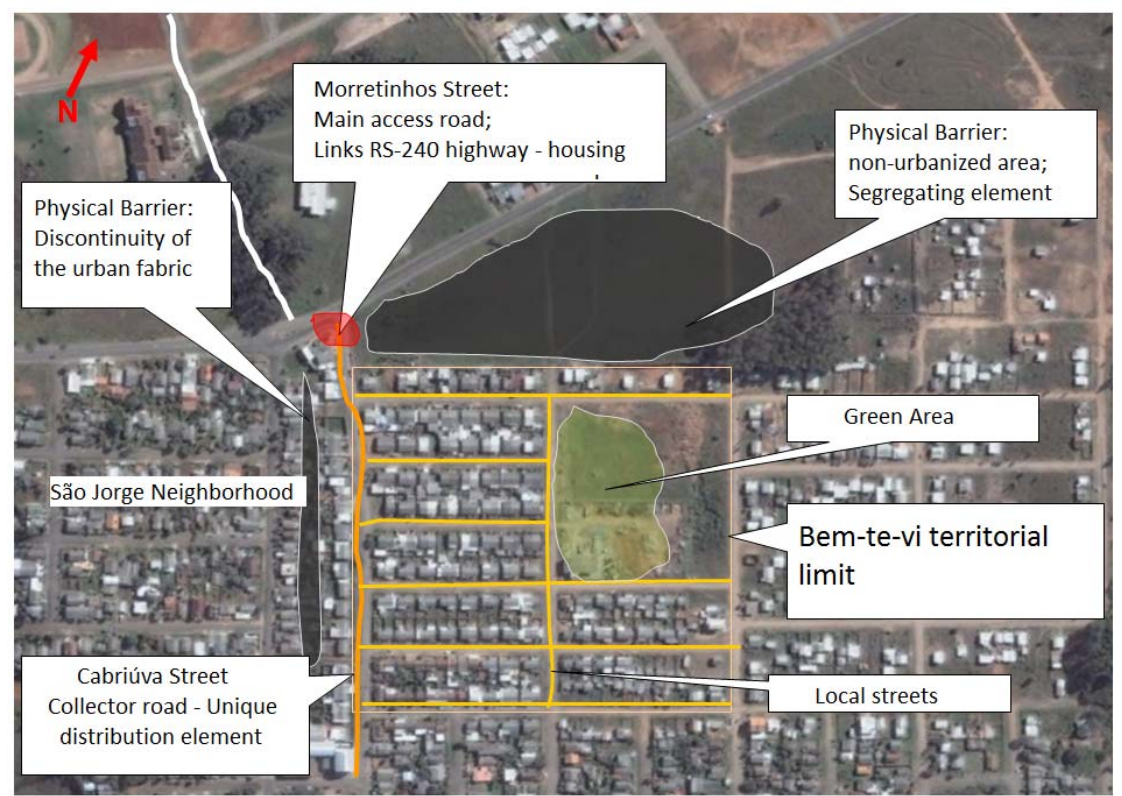

Fig. 4 Spatial representation of Bem-te-vi housing, Portão/RS.

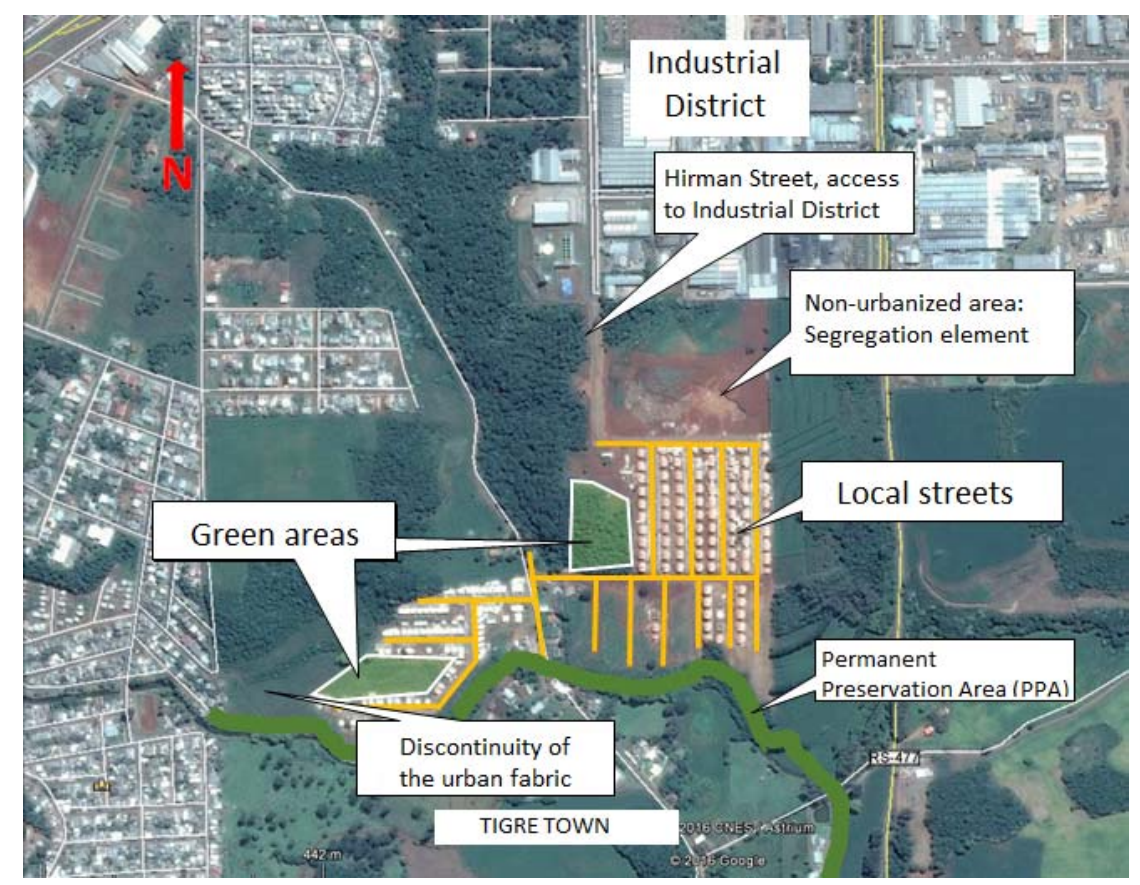

Fig. 5 Spatial representation of Rio Tigre housing, Erechim/RS.

carried out in non-urbanized area. The development comprises a total area of $115,109.61 \mathrm{~m}^{2}$, of which $54.21 \%$ are occupied by lots, $29.96 \%$ by road networks, $11.68 \%$ for the green area and $5.14 \%$ for public facilities.

These spaces needs to be designed with suitable lot subdivisions aimed to local sustainability, which favors the municipal technical work as suits urban policies focused on meeting the needs of residents [25]. Thus, Bem-te-vi was divided by the insertion of the orthogonal road network, where it was used the closed-loop system, resulting in smaller and regular blocks, which allowed a better space occupation in a sustainable manner (Fig. 4). 
While in Rio Tigre, it was used in its implementation an orthogonal grid that alternates in open (inside the plot) and closed-loops (near the borders). The implementation orthogonality, in this case, disregards the uneven site topography, resulting in lots and roads with steep slopes (Fig. 5).

The use of rectangular blocks in the construction of the two surveyed housing developments was observed. In Bem-te-vi, the rectangular blocks have 32 lots each and measure $142.5 \times 48.5 \mathrm{~m}^{2}$, with a total area of $6,911.25 \mathrm{~m}^{2}$. In the housing development of Erechim, three major blocks with area $8,800.00 \mathrm{~m}^{2}$ hold 44 lots with $187 \mathrm{~m}^{2}$ on average. These lots have average facade of $8.5 \mathrm{~m}$ by $22 \mathrm{~m}$ depth, which could reduce infrastructure deployment costs by almost $20 \%$, facilitating future maintenance [26].

The shorter block length of Bem-te-vi is $142.5 \mathrm{~m}$ that, besides presents a great gross area (72\%), it facilitates internal circulation and the interaction of the residents due to the shorter route, as well as reducing infrastructure deployment costs by shorter distance employed. While in Rio Tigre, there are blocks with dimensions of only $90 \mathrm{~m}$, resulting from the adaptation of topography and environmental conditions, including the presence of native forest and the PPA (permanent preservation areas).

Regarding Table 2, it can be observed that the percentages cited [1] significantly differ from those employed in the implementation of the pavement and drainage network of both housing developments. Such values discrepancy can be understood by the use of basaltic stone for paving road systems of the studied housings. Furthermore, in the case of Rio Tigre and its uneven topography, the construction of an efficient drainage system presents a high cost. The lack of investment in an efficient drainage system is observed in loco due to problems in stormwater runoff.

According to data collected by questionnaire, in general, residents of both locations are satisfied with the housing developments. These residents, when questioned to classify their housing development as a whole, presented the following results for Bem-te-vi: $73.9 \%$ rated it as good, $19.6 \%$ as bad, $4.3 \%$ as great and $2.2 \%$ as very bad considering infrastructure, urban context and availability of commerce and services. While in Rio Tigre, 65\% evaluated it as good, $25 \%$ as bad, $5 \%$ as great and $5 \%$ as very bad.

Another issue raised in the POE (post occupancy evaluation) was the most frequent requests from residents about the lack of infrastructure equipment. Most requests (25\%) in Bem-te-vi regard the green area. While in Rio Tigre, the main request is related to commerce. These figures present lack of infrastructure, directly affecting the residents' quality of life (Fig. 6).

Table 2 Cost average percentage comparative per network in housing developments Bem-te-vi and Rio Tigre, as suggested by Mascaró (1987).

\begin{tabular}{llll}
\hline Network infrastructure & $\begin{array}{l}\text { Mascaró (1987) low density area } \\
(\%)\end{array}$ & Bem-te-vi & Rio Tigre \\
\hline Landscaping & - & $426,782.63$ & $6.12 \%$ \\
Drainage network & 14.38 & $5.33 \%$ & $6.75 \%$ \\
Public lighting and electricity & 14.12 & $6.50 \%$ & $13.65 \%$ \\
Water network & 3.93 & $1,123,113.04$ & $2.97 \%$ \\
Pavement & 41.38 & $14 \%$ & $28.35 \%$ \\
Sewage network & 17.10 & $2.07 \%$ & 15.022 .43 \\
Terrain cost & - & $2,069,156.50$ & $15.86 \%$ \\
\hline Total & $100 \%$ & $1,288,400.29$ & $27.30 \%$ \\
\hline
\end{tabular}

Source: Adapted from Mascaró (1987) and from the housings project data. 

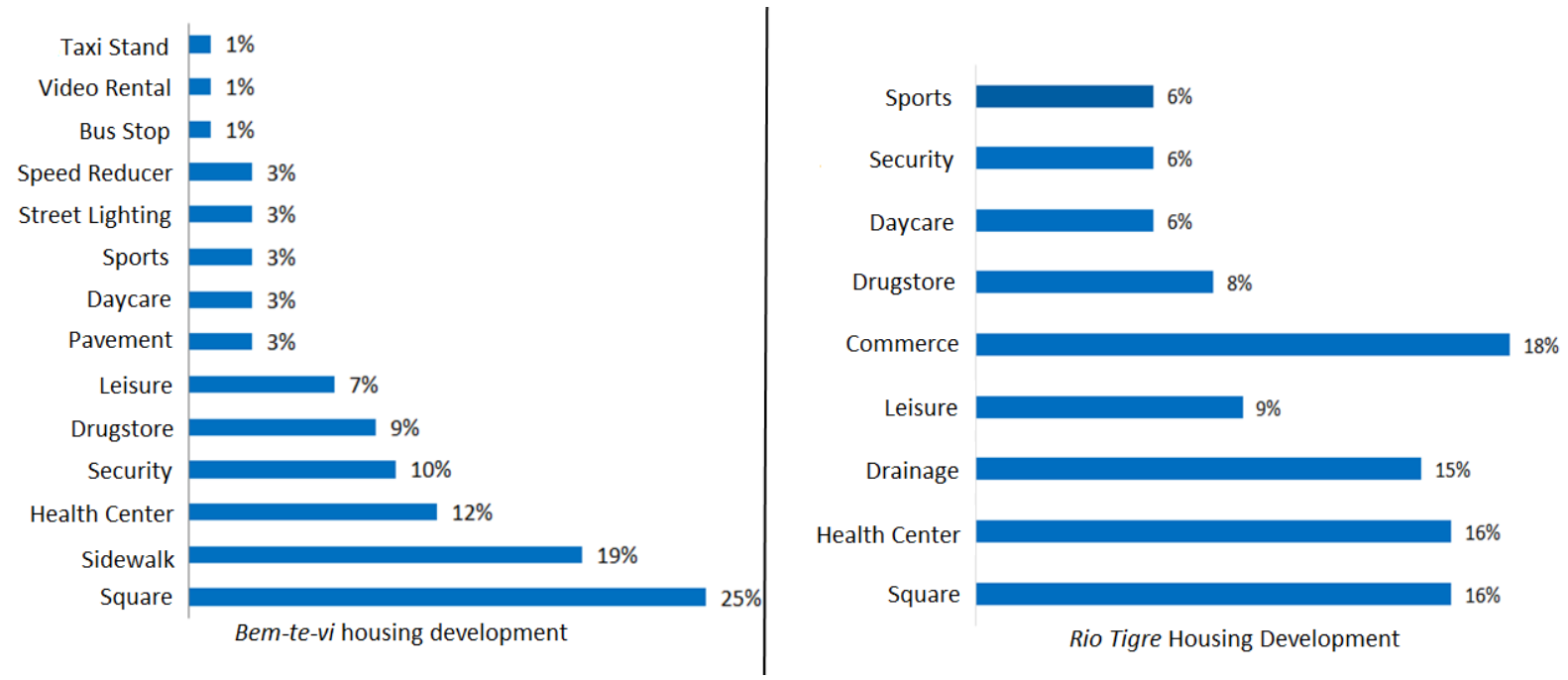

Fig. 6 Residents needs of Bem-te-vi and Rio Tigre housing developments.

It is noticed that, in the implementation of Bem-te-vi, it was not prioritized the collective use of space as the green area is on the outskirts of the settlement. Perpendicular to local roads, the only collector street of the venture, called Cabriúva Street, connects to the main link with various neighborhoods of the city and the highway RS-240, Morretinhos Street. In the immediate surroundings, St. George neighborhood can be found in the west of the housing development and an irregular settlement is located in the east with major infrastructure problems. The idea of open community does not exist because the circulation system does not connect the housing development and the surroundings. Whereas in Rio Tigre, it presents isolation from the urban fabric representing a segregation character, since access to the housing is made by two ways (Hirmam Sampaio Street and Virgilio Biolo Street) that run through not urbanized areas. The immediate surrounding presents the Tigre Town in the south and areas of native forest and farms in all other directions. The closest commerce is located in the Industrial District to the north apart $500 \mathrm{~m}$ from the sole collector street of the development.

The implementation of Rio Tigre is apparently the imposition of the orthogonal layout on the uneven topography, resulting in lots with unevenness higher than $4 \mathrm{~m}$, that causes frequent problems with drainage infrastructure when heavy rains occur. The connection to the urban fabric is made by Virgilio Biolo Street that is connected to the Industrial District and the Highway RS-153, and by Hirman Sampaio Street, linked solely to the Industrial District. The isolation of the settlements in relation to the urban environment causes difficulty of access to markets and services, which is aggravated by the residential character of the enterprise in question.

This lack of integration between urban neighborhoods needs to be reconsidered with layout studies. Previous layout studies can achieve solutions to modify the current situation of many Brazilian cities, including enhanced social interaction [5, 27]. In this case, the built environment would require to be rebuilt or implemented with appropriate links of their neighborhoods to the city center, hence projecting the urban growth rates with innovation factors of architectural sustainability of the environment $[5,11,27]$.

\section{Conclusions}

Primarily, the research was developed with theoretical review and analysis of alternative systems designed for infrastructure networks, as well as study of other works related to the theme, trying to understand the relationship between infrastructure and environment. In a second stage, it was identified and 
analyzed the infrastructure quality of a low-income housing development located in Portão. In addition to the physical survey, relevant data were obtained through questionnaires, revealing information that eased the understanding of the links between environment and users, making possible to investigate opportunities and weaknesses.

Literature review organization and survey created an important base of information for other research stages related to alternative technologies with less environmental impacts. Moreover, it was possible to contribute in research of urban infrastructure, noticing the scarce bibliography on the subject. The case study partially covers the implemented infrastructure networks: rainwater drainage, electricity supply, individual sewage collection, water supply and street lighting.

The survey revealed that in the case of Bem-te-vi, the choice of deployment area was adequate, given the proximity to a consolidated district, which facilitated the support of urban equipment, the public transport through an existing network and interaction between communities. In contrast, it was observed a clear isolation resulting from the adopted design and absence of continuity or common identity among the districts.

In the case of Rio Tigre, location selection was not appropriate because it was placed on a peripheral site and outside the urban area zone, resulting in difficulty of access to public facilities, commerce and services for residents, which is aggravated by the industrial characteristic of the surrounding neighborhood.

In this context, it is possible to observe from the evaluation table of the housing developments quality that the residents recognize the problems, presenting the value of post-occupancy evaluation and the strong influence that residents' interests can exercise on urban design. Therefore, target audience analysis becomes an important element and a strong support tool in the design process.

This research has exposed and reaffirmed the importance of the relationship between men, human settlement and environment. At the same time, it revealed the secondary role given to low-income housing planning, as for the lower quality of executed models, whose main concern is to distribute a large number of lots in a given area, which turns out to reflect in the residents' quality of life. The urban housing project, erroneously concerned about the minor portion (private lot), must be reconsidered in order to reverse the design process, taking advantage of infrastructure networks as structural elements and not just as constraints in the process.

Thus, it is expected that the information of this article could contribute to projective processes of urban housing developments and to environmental infrastructure research, enabling the development of quality urban scenarios aiming to achieve a better economical, social and environmental condition, supporting the suggestions that reported the need to increase the number of housings designed to meet the needs of homelessness, and thus meet a large population demand [6, 7].

Some recommendations for future work can be made: relate alternative infrastructure and implementation costs in low-income housing; extend permaculture concepts and practices in urban infrastructure networks and analyze implemented infrastructure in ecological settlement projects, for example, ecovillages.

The adopted morphology of regular grid pattern is regularly used in this type of development and aims to facilitate infrastructure implementation and reduce deployment costs. However, disregards the user's interaction with the public space by using undersized networks, which can be observed on the sidewalks width, the non-existent arboreal network, the lack of green areas for leisure and sport, the unfinished and discontinuous pavement, result in a debilitated urban space that basically focuses on sheltering and lot private area.

Land use is often influenced by terrain steepness, 
which results in increased costs for construction, because housing foundations need to be further strengthened, what can be observed in Rio Tigre. However, both examined locations require houses with balconies closer to streets; placement of parking spaces, clearing sidewalks for walking; and the implementation of mixed housings (commercial and residential) would eventually consolidate meeting points, enabling interaction between the inhabitants of the settlements.

The creation of housing development projects needs to be designed wisely, linking through alternatives ways the central areas of the built environment, designing together, considering urban growth rates, with innovative factors and architectural sustainability of the environmental $[5,11,27]$.

\section{References}

[1] Mascaró, J. L. 1989. Desenho Urbano e Custos de Urbanização (Urban Design and Urbanization Costs). Porto Alegre: Sagra Luzzatto. (in Portuguese)

[2] Santos, A. S. R. 1996. "Caos Urbano: Preocupação Mundial.” Diadema Jornal, São Paulo, Feb. 15th.

[3] Sánchez, L. E. 2013. Avaliação de Impacto Ambiental: Conceitos e Métodos (Environmental Impact Assessment: Concepts and Methods). 2nd ed. São Paulo: Oficina de Textos. (in Portuguese)

[4] Kattel, G. R., Elkadi, H., and Meikle, H. 2013 "Developing a Complementary Framework for Urban Ecology." Urban Forestry \& Urban Greening 12 (4): 498-508.

[5] Grant, R. 2015. "Sustainable African Urban Futures: Stocktaking and Critical Reflection on Proposed Urban Projects." American Behavioral Scientist 59 (3): 294-310.

[6] Körbes, A. S. 2008. “Os Condomínios Fechados Horizontais de Cacupé no Contexto Urbano de Florianópolis: Os Lugares fora do Lugar (The Horizontal Closed Condos of Cacupé in Florianópolis Urban Context: The Places Outside the Place.)." Dissertação (Mestrado em Geografia), Faculdade de Filosofia e Ciências Humanas da Universidade Federal de Santa Catarina, Florianópolis. (in Portuguese)

[7] Sanga, S. A. 2015. "Intra-urban Residential Mobility and Tenants' Workplace Choices in Kinondoni Municipality." Habitat International 49: 45-55.

[8] Oliveira, A. C. R. 2013. "Agentes e Efeitos da Especulação Imobiliária em Ponta Grossa-PR.” Ra'e Ga: O Espaço Geográfico em Análise 28 (1): 106-33. (in
Portuguese)

[9] Castello, I. R. 2008. Bairros, Loteamentos e Condomínios: Elementos para o Projeto de Novos Territórios Habitacionais (Neighborhoods, Allotments and Condos: Elements for New Territories Housing Projects). Porto Alegre: UFRGS. (in Portuguese)

[10] Yoshinaga, M. 2003. "Infra-estrutura Urbana e Plano Diretor." Revista Vitruvius 3 (3): 36-9. (in Portuguese)

[11] Dong, H., and Zhu, P. 2015. "Smart Growth in Two Contrastive Metropolitan Areas: A Comparison between Portland and Los Angeles." Urban Studies 52 (4): 775-92.

[12] Caminos, H., and Goethert, R. 1984. Elementos de Urbanizacion (Urbanization Elements). México: Gustavo Gilli. (in Portuguese)

[13] Aymonino, C. 1984. O Significado das Cidades (The Meaning of Cities). Lisboa. Editorial Presença. (in Portuguese)

[14] Pereira, R. B. 2012. "Tipologia Arquitetônica e Morfologia Urbana: Uma Abordagem Histórica de Conceitos e Métodos (Architectural Typology and Urban Morphology: A Historical Approach of Concepts and Methods)." Arquitextos 13 (146): 04. (in Portuguese)

[15] Rego, L. F. G. 2014. "Urban Vegetable Production for Sustainability: The Riortas Project in the City of Rio de Janeiro, Brazil." Habitat International 44: 510-6.

[16] Instituto de Geografia e Estatística. 2015. Censo Demográfico, 2010 (Census 2010). Instituto de Geografia e Estatística. Accessed September 17, 2015. http://www.ibge.gov.br. (in Portuguese)

[17] Instituto de Geografia e Estatística. 2014. Mapa da localização de Portão/RS, 2014 (Location Map of Portão/RS, 2014). Instituto de Geografia e Estatística. Accessed December 17, 2014. http://www.ibge.gov.br. (in Portuguese)

[18] QGIS (Open Source Geographic Information System). 2014. Version 2.4: Source Geographic Information system: Project of the Open Source Geospatial Foundation (OSGeo). QGIS.

[19] Socioeconomic Atlas Of Rio Grande Do Sul. 2010. Informações da População. Socioeconomic Atlas Of Rio Grande Do Sul. Accessed September 24, 2015. http://www.scp.rs.gov.br/atlas/conteudo.asp?cod_menu_f ilho $=806 \&$ cod_menu $=805 \&$ tipo_menu $=$ POPULA\&cod_ conteudo $=1386$. (in Portuguese)

[20] Babbie, E. 2003. Métodos de Pesquisa de Survey (Research Survey Methods). Belo Horizonte: UFMG. (in Portuguese)

[21] Ornstein, S. W. "Inserção Urbana e Avaliação Pós-ocupação (APO) da Habitação de Interesse Social (Urban Insertion and Post-occupancy Evaluation (POE) of the Social Housing)." In Coletânea Habitare. São Paulo: FAUUSP. (in Portuguese) 
[22] Prefeitura Municipal de Portão. 2010. Bem-te-vi Allotment Data. Accessed September 15, 2014. http://www.portao.rs.gov.br.

[23] Prefeitura Municipal de Erechim. 2015. Rio Tigre Allotment Data. Accessed December 6, 2015. http://www.pmerechim.rs.gov.br/. (in Portuguese)

[24] Brasil. 2002. Estatuto da Cidade: Lei 10.257/2001 que Estabelece Diretrizes Gerais da Política Urbana (City Statute: Law 10.257/2001 that Establishes General Guidelines of Urban Policy). Brasília: Câmara dos
Deputados. (in Portuguese)

[25] Wan, C., and Shen, G. Q. "Salient Attributes of Urban Green Spaces in High Density Cities: The Case of Hong Kong.” Habitat International 49: 92-9.

[26] Mascaró, J. L. 1987. Manual de Loteamentos $e$ Urbanização (Allotments and Urbanization Manual). Porto Alegre: Sagra Luzzatto. (in Portuguese)

[27] Cabrera, J. F., and Najarian, J. C. "How the Built Environment Shapes Spatial Bridging Ties and Social Capital.” Environment and Behavior 47 (3): 239-67. 